\title{
Screening of Seed Soluble Sugar Content in Cowpea (Vigna unguiculata (L.) Walp)
}

\author{
Yuejin Weng1, Waltram Second Ravelombola1, Wei Yang1, Jun Qin1, Wei Zhou1, Y.-J. Wang2, \\ Beiquan Mou ${ }^{3 *}$, Ainong Shi ${ }^{*}$
}

\author{
${ }^{1}$ Department of Horticulture, University of Arkansas, Fayetteville, AR, USA \\ ${ }^{2}$ Department of Food Science, University of Arkansas, Fayetteville, AR, USA \\ ${ }^{3}$ US Department of Agriculture, Agricultural Research Service (USDA-ARS), Salinas, CA, USA \\ Email: ^ashi@uark.edu, ^Beiquan.Mou@ARS.USDA.GOV
}

How to cite this paper: Weng, Y.J., Ravelombola, W.S., Yang, W., Qin, J., Zhou, W., Wang, Y.-J., Mou, B.Q. and Shi, A.N. (2018) Screening of Seed Soluble Sugar Content in Cowpea (Vigna unguiculata (L.) Walp). American Journal of Plant Sciences, 9, 1455-1466

https://doi.org/10.4236/ajps.2018.97106

Received: May 1, 2018

Accepted: June 18, 2018

Published: June 21, 2018

Copyright (ㅇ 2018 by authors and Scientific Research Publishing Inc. This work is licensed under the Creative Commons Attribution International License (CC BY 4.0).

http://creativecommons.org/licenses/by/4.0/

\begin{abstract}
Cowpea (Vigna unguiculata (L.) Walp) is a legume crop grown worldwide to provide protein, starch, soluble sugar, amino acids, fatty acids, minerals, and vitamins for human consumption and animal feed. Soluble sugar is an important physiological trait in cowpea seeds. It not only plays an important role in storability and abiotic stress tolerance in seeds, but also provides energy to the human body and improves cooking quality by giving a desirable taste and mouth feel. Therefore, this research aimed to evaluate variation of cowpea seed soluble sugar content, and assess the soluble sugar content of cowpea varieties with different seed coat colors for cowpea consumers. A total of 113 cowpea genotypes were used, including 89 USDA GRIN germplasm accessions and 24 advanced breeding lines developed from University of Arkansas, AR, USA. Seed soluble sugar content was measured using a Spectrophotometer by phenol-sulphuric acid method. The results showed that the seed soluble sugar contents among 113 cowpea genotypes exhibited a wide range varying from $32.6 \mathrm{mg} / \mathrm{g}$ to $86.1 \mathrm{mg} / \mathrm{g}$ with an average of $54.5 \mathrm{mg} / \mathrm{g}$. The five highest soluble sugar contents in seeds were found in the Arkansas cultivar Empire $(86.1 \mathrm{mg} / \mathrm{g})$, USDA germplasm accession PI583202 (84.5 mg/g), Arkansas advanced breeding line 09-655 (82.1 mg/g), USDA accession PI601085 (81.6 $\mathrm{mg} / \mathrm{g})$, and Arkansas advanced breeding line 09-529 (80.9 mg/g), and they can be used in cowpea breeding programs to develop new cowpea cultivars with higher seed soluble sugar content. It was also observed that the soluble sugar contents in Arkansas commercial cultivars and advanced breeding lines were higher than those in USDA germplasm and the seeds with colorful coat may have soluble sugar levels desirable by consumers.
\end{abstract}

\section{Keywords}

Seeds Storage, Soluble Sugar, Germplasm, Seed Color 


\section{Introduction}

Cowpea (Vigna unguiculata (L.) Walp), a legume crop that is grown worldwide, is beneficial for human consumption, animal feed and the environment [1]-[6]. It was estimated that, the total area under production amounts to about 14 million hectares with an annual production of over 5.4 million tones worldwide [7] [8]. Cowpea is widely distributed throughout the tropics, but Central and West Africa amounts to 64 percent of the area with about 8 million hectares followed by about 2.4 million hectares in Central and South America, 1.3 million hectares in Asia and about 0.8 million hectares in East and Southern Africa [9]. Cowpea is also grown as a vegetable (both for the leafy greens and the green peas). It primarily provides protein, starch, soluble sugar, amino acids, fatty acids, minerals and vitamins which benefit human health.

The content of soluble sugar is an important physiological trait which influences cooking quality in seeds and seed production [1] [10] [11] [12]. In fact, cowpea breeding has to feature traits desired by consumers in the market as well as farmers. The "sweet" trait, characterized by a sweeter and milder taste could help broaden cowpea consumption in the market. It not only provides calories as energy to human body, but also improves the cooking quality by producing a desirable taste and mouth feel. Additionally, soluble sugar has been proposed to play an important role in storability and abiotic stress tolerance in seeds, which are highly sensitive to environmental stresses [13]. Increases in levels of sugar in seeds have been correlated with the onset of desiccation tolerance during seed development [14]. Similarly, the loss of these soluble sugars in seeds at the beginning of germination has been found to coincide with the re-acquisition of desiccation sensitivity [15]. Seed longevity and development have also been positively correlated with the level of soluble sugars in seed [16].

However, this seed soluble sugar content characteristic has not received much attention in the cowpea breeding program, which has been primarily concerned with increasing yield, pest resistance, draught tolerance, protein content and other quality characteristics [3] [4] [17]. A few articles have reported on variable soluble sugar content in different genotypes in cowpea. Baptiste et al. (2011) reported three methods measuring soluble sugar content in cowpea seeds [1]. Nassourou et al. (2017) assessed the amount of total soluble sugar among 15 fully homozygous cowpea cultivars using the phenol sulfuric acid reagent method [3]. The objective of the present work was to evaluate the soluble sugar content in cowpea seeds and investigate elite germplasm with desired soluble sugar contents in order to propose a suitable breeding strategy for improving sweetness of cowpea seeds.

\section{Materials and Methods}

\subsection{Plant Materials}

A total of 113 cowpea genotypes (Table 1 ) were used in this study, including 89 USDA GRIN cowpea accessions and 24 advanced breeding lines from the cowpea 
Table 1. List of cowpea genotypes and their mean soluble sugar content.

\begin{tabular}{|c|c|c|c|}
\hline Genotypes & Genetic background & Seed coat color & Content (mg/g) \\
\hline $01-1781$ & AR breeding_line & Cream & 60.60 \\
\hline 07-303 & AR breeding_line & Red & 74.02 \\
\hline 09-105 & AR breeding_line & Cream & 68.08 \\
\hline $09-1090$ & AR breeding_line & Pinkeye & 77.20 \\
\hline 09-204 & AR breeding_line & Browneye & 71.17 \\
\hline $09-208$ & AR breeding_line & Pinkeye & 78.68 \\
\hline $09-211$ & AR breeding_line & Pinkeye & 69.51 \\
\hline 09-393 & AR breeding_line & Pinkeye & 62.20 \\
\hline $09-455$ & AR breeding_line & Blackeye & 73.99 \\
\hline $09-462$ & AR breeding_line & Pinkeye & 71.58 \\
\hline $09-529$ & AR breeding_line & Blackeye & 80.94 \\
\hline $09-655$ & AR breeding_line & Pinkeye & 82.05 \\
\hline $09-671$ & AR breeding_line & Blackeye & 72.02 \\
\hline $09-686$ & AR breeding_line & Pinkeye & 75.42 \\
\hline $09-692$ & AR breeding_line & Pinkeye & 74.34 \\
\hline $09-697$ & AR breeding_line & Pinkeye & 61.67 \\
\hline $09-714$ & AR breeding_line & Pinkeye & 70.21 \\
\hline $09-741$ & AR breeding_line & Red Holstein & 77.20 \\
\hline AR Blackeye \#1 & AR cultivar & Blackeye & 70.24 \\
\hline AR95-348 & AR cultivar & Red & 60.74 \\
\hline Early Acre & AR cultivar & Cream & 54.50 \\
\hline Early Scarlet & AR cultivar & Pinkeye & 65.69 \\
\hline Ebony & AR cultivar & Black & 69.10 \\
\hline Empire & AR cultivar & Pinkeye & 86.05 \\
\hline PI152195 & Germplasm & Red & 41.66 \\
\hline PI152197 & Germplasm & Red & 41.02 \\
\hline PI201498 & Germplasm & Blackeye & 70.16 \\
\hline PI218123 & Germplasm & Browneye & 48.10 \\
\hline PI220851 & Germplasm & Browneye & 47.83 \\
\hline PI223023 & Germplasm & Browneye & 44.75 \\
\hline PI229734 & Germplasm & Blackeye & 65.39 \\
\hline PI250587 & Germplasm & Blackeye & 74.66 \\
\hline PI253428 & Germplasm & Black & 38.89 \\
\hline PI255765 & Germplasm & Black & 43.49 \\
\hline PI255774 & Germplasm & Browneye & 37.15 \\
\hline PI262179 & Germplasm & Black & 44.43 \\
\hline PI291140 & Germplasm & Black & 49.29 \\
\hline PI292898 & Germplasm & Black & 40.77 \\
\hline PI293477 & Germplasm & Black & 38.81 \\
\hline
\end{tabular}




\section{Continued}

\begin{tabular}{|c|c|c|c|}
\hline PI293505 & Germplasm & Black & 39.01 \\
\hline PI293586 & Germplasm & Black & 44.00 \\
\hline PI293587 & Germplasm & Red & 41.34 \\
\hline PI293588 & Germplasm & Black & 41.44 \\
\hline PI311119 & Germplasm & Red & 42.65 \\
\hline PI312210 & Germplasm & Browneye & 47.30 \\
\hline PI339588 & Germplasm & Black & 42.65 \\
\hline PI339599 & Germplasm & Browneye & 46.79 \\
\hline PI339605 & Germplasm & Red & 41.64 \\
\hline PI349674 & Germplasm & Black & 46.08 \\
\hline PI354673 & Germplasm & Black & 50.52 \\
\hline PI354805 & Germplasm & Red & 41.19 \\
\hline PI354832 & Germplasm & Black & 32.55 \\
\hline PI354835 & Germplasm & Black & 39.08 \\
\hline PI354843 & Germplasm & Black & 41.29 \\
\hline PI354854 & Germplasm & Red & 46.80 \\
\hline PI354860 & Germplasm & Black & 39.43 \\
\hline PI354864 & Germplasm & Black & 39.19 \\
\hline PI354865 & Germplasm & Black & 36.26 \\
\hline PI406285 & Germplasm & Blackeye & 45.63 \\
\hline PI406290 & Germplasm & Browneye & 48.28 \\
\hline PI406292 & Germplasm & Browneye & 56.79 \\
\hline PI427093 & Germplasm & Black & 46.75 \\
\hline PI430687 & Germplasm & Red & 50.16 \\
\hline PI548785 & Germplasm & Blackeye & 62.69 \\
\hline PI578902 & Germplasm & Red & 49.77 \\
\hline PI578911 & Germplasm & Red & 45.94 \\
\hline PI582352 & Germplasm & Black & 47.62 \\
\hline PI582353 & Germplasm & Black & 47.20 \\
\hline PI582422 & Germplasm & Blackeye & 67.06 \\
\hline PI582428 & Germplasm & Blackeye & 64.28 \\
\hline PI582466 & Germplasm & Blackeye & 58.37 \\
\hline PI582474 & Germplasm & Black & 38.95 \\
\hline PI582551 & Germplasm & Blackeye & 52.42 \\
\hline PI582573 & Germplasm & Browneye & 71.07 \\
\hline PI582575 & Germplasm & Black & 38.52 \\
\hline PI582702 & Germplasm & Red & 51.58 \\
\hline PI582815 & Germplasm & Red & 42.11 \\
\hline PI582863 & Germplasm & Browneye & 74.92 \\
\hline PI582868 & Germplasm & Red & 40.42 \\
\hline PI582923 & Germplasm & Blackeye & 51.60 \\
\hline
\end{tabular}




\section{Continued}

\begin{tabular}{|c|c|c|c|}
\hline PI582926 & Germplasm & Browneye & 63.10 \\
\hline PI582942 & Germplasm & Cream & 46.86 \\
\hline PI583195 & Germplasm & Red & 46.04 \\
\hline PI583197 & Germplasm & Black & 46.26 \\
\hline PI583200 & Germplasm & Blackeye & 42.86 \\
\hline PI583201 & Germplasm & Browneye & 63.17 \\
\hline PI583202 & Germplasm & Browneye & 84.53 \\
\hline PI583232 & Germplasm & Black & 47.61 \\
\hline PI583248 & Germplasm & Browneye & 64.35 \\
\hline PI583250 & Germplasm & Browneye & 62.67 \\
\hline PI583513 & Germplasm & Blackeye & 43.70 \\
\hline PI583551 & Germplasm & Browneye & 62.37 \\
\hline PI592369 & Germplasm & Cream & 46.69 \\
\hline PI592374 & Germplasm & Cream & 46.51 \\
\hline PI601085 & Germplasm & Browneye & 81.57 \\
\hline PI601682 & Germplasm & Browneye & 79.31 \\
\hline PI608035 & Germplasm & Blackeye & 51.00 \\
\hline PI610520 & Germplasm & Black & 47.92 \\
\hline PI610533 & Germplasm & Blackeye & 45.79 \\
\hline PI610620 & Germplasm & Black & 43.14 \\
\hline PI642160 & Germplasm & Blackeye & 55.56 \\
\hline PI662992 & Germplasm & Cream & 46.33 \\
\hline PI663101 & Germplasm & Blackeye & 61.23 \\
\hline PI663140 & Germplasm & Cream & 45.98 \\
\hline PI663148 & Germplasm & Blackeye & 45.80 \\
\hline PI663151 & Germplasm & Cream & 45.80 \\
\hline PI664515 & Germplasm & Cream & 45.62 \\
\hline PI664517 & Germplasm & Blackeye & 47.80 \\
\hline PI664518 & Germplasm & Cream & 45.45 \\
\hline PI664519 & Germplasm & Cream & 45.27 \\
\hline PI664524 & Germplasm & Blackeye & 62.49 \\
\hline PI666253 & Germplasm & Cream & 46.15 \\
\hline PI666262 & Germplasm & Pinkeye & 66.85 \\
\hline
\end{tabular}

breeding program at the University of Arkansas, AR, USA. The field experiment was conducted in three different locations within Arkansas State (Fayetteville, Alma, and Hope) in 2016. During the growing season, no pesticides or herbicides were sprayed to control pests, diseases, and weeds. Cowpea seeds were harvested when the color of pods changed and became mature. Seeds were dried and stored at room temperature until the soluble sugar measurement at laboratory. 
Cowpea seed coat color is an important commercial trait to breeders in nursery and consumers in the market because cowpea has a diversity of colorful seed coats (Figure 1). Six seed color patterns were included in this study: black, blackeye, browneye, cream, pinkeye, and red color.

\subsection{Sample Preparation}

Within each location, seeds from each row were bulk-harvested. Seed soluble sugar content referred to the total sugar content was extracted using the following protocol. An $20 \mathrm{~g}$ of cowpea seeds of each sample was ground using a coffee grinder (Hamilton Beach) for 1 min. 2 or $3 \mathrm{~g}$ portion of the ground flours was sieved through 100\# (nominal wire diameter $0.1 \mathrm{~mm}$, Seedburo Equipment Company). $1.0 \mathrm{~g}$ of each sample was weighed and then transferred to a $50 \mathrm{ml}$ microfuge tube. And then $40 \mathrm{ml} 80 \%$ ethanol was added to each tube, homogenized for $1 \mathrm{~min}$ in a vortex and placed in a water bath at $80^{\circ} \mathrm{C}$ for $20 \mathrm{~min}$. After this treatment, the tubes were centrifuged at $6000 \mathrm{rpm}$ for $10 \mathrm{~min} .2 \mathrm{ml}$ of the supernatant was then transferred into a $100 \mathrm{ml}$ fresh flask to be diluted 50 times.

\subsection{Equipment}

GENESYS $^{\mathrm{TM}} 20$ Visible Spectrophotometry (Thermo Scientific USA), an instrument which determines the amount of light absorbed while passing through a sample, was used to measure soluble sugar in seeds at laboratories, Department of Food Science, University of Arkansas, Fayetteville, Arkansas, USA.

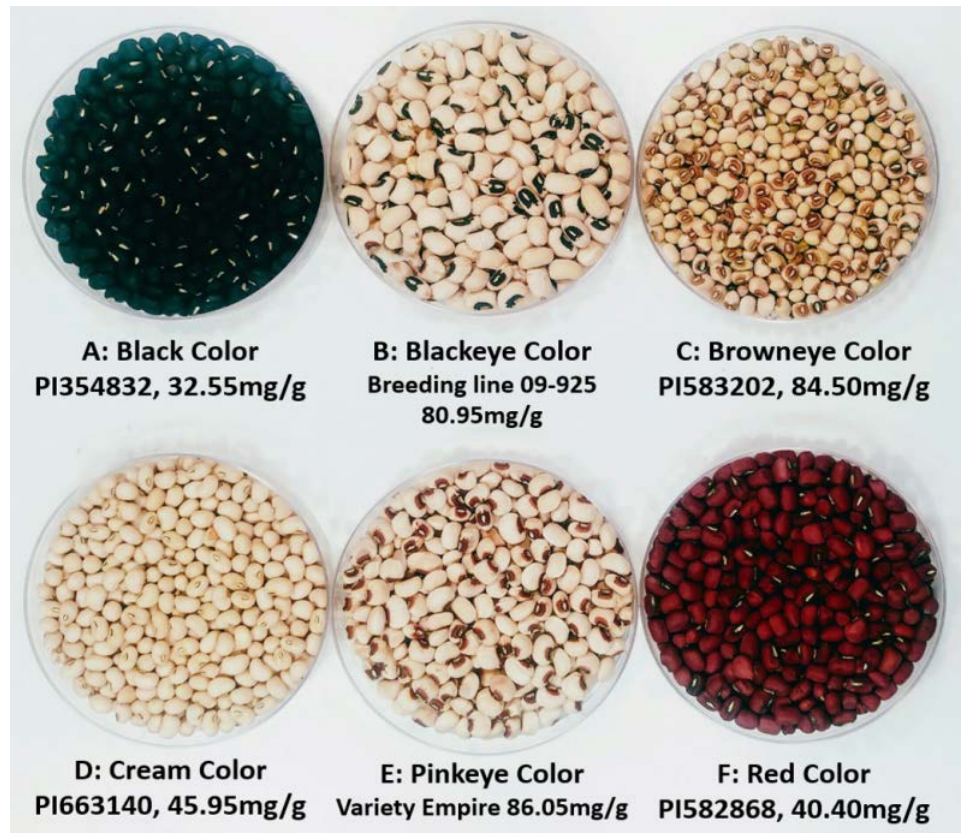

Figure 1. Six seed coat color patterns in cowpea: (A) Black color (ex. PI354832, $32.55 \mathrm{mg} / \mathrm{g}$ ); (B) Blackeye color (breeding line 09-925, 80.94 $\mathrm{mg} / \mathrm{g}$ ); (C) Browneye color (PI583202, $84.53 \mathrm{mg} / \mathrm{g}$ ); (D) Cream color (PI663140, 45.98 mg/g); (E) Pinkeye color (cultivar Empire, 86.05 mg/g); and (F) Red color (PI582868, $40.42 \mathrm{mg} / \mathrm{g}$ ). 


\subsection{Standard Curve Establishment}

The amount of total soluble sugar was measured by the phenol-sulfuric acid reagent method [18]. A total of $50 \mathrm{ml}$ of glucose (AR, Sigam-Alorich) stock solutions were prepared at the following concentrations: $0,10,30,50,70$, and 100 $\mu \mathrm{g} / \mathrm{ml}$ standard curve for glucose. Then $0 \mathrm{ml} ; 0.5 \mathrm{ml} ; 1.5 \mathrm{ml} ; 3.5 \mathrm{ml}$; and $5.0 \mathrm{ml}$ of glucose stock solution were each poured into a $10 \mathrm{ml}$ recipient. $1 \mathrm{ml}$ was taken from each solution and poured into a test tube for measurement of soluble sugar content with colorimetric phenol-sulfuric acid by Spectrophotometry.

After many repetitions, a standard glucose curve with concentration $0,10 \%$, $30 \%, 50 \%, 70 \%$ and $100 \%$ was set up in this study (Figure 2). Six points look smooth and straight without double to be determined, known as the smooth curve. The best standard curves having the equation $\mathrm{Y}=0.0039 \mathrm{X}+0.0235\left(\mathrm{R}^{2}=\right.$ 0.99878 ) was achieved and accomplished consummation, where $\mathrm{X}$ is absorbance coefficient at $490 \mathrm{~nm}$ wavelength on Spectrophotometer and Y is soluble sugar content (\%) in cowpea seed storage. Daily repeats allowed a soluble sugar standard curve to be constructed which was used to determine the soluble sugar concentration in each cowpea sample.

\subsection{Quality Assessment}

The use of phenol-sulfuric acid with a phenol concentration of $2 \%$ provided a relatively simple and reliable colorimetric method to quantify the total soluble-sugar concentration. Spectrophotometer measures the absorbance with wavelength at $490 \mathrm{~nm}$. Absorbance was estimated using Beer's law:

$$
a b c=\log \left(I_{0} / I\right)
$$

$I_{0}$ : incident radiation or radiation transmitted.

I: radiation transmitted by the sample.

$a b c$ absorbance of the sample.

a: absorbancy coefficient.

$b$ : path length of the sample.

c. concentration of the sample.

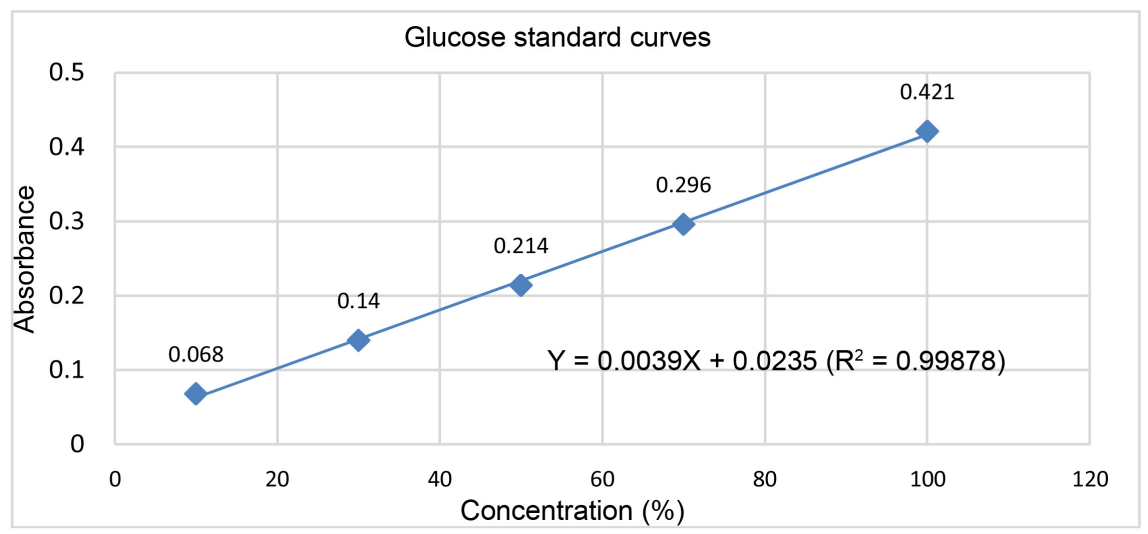

Figure 2. Glucose standard curves was computer generated based on the five standard concentrations. 
Based on each sample's absorbent value, the concentration of total soluble sugar in each cowpea sample was estimated using the regression equation form the standard curve. Individual extractions were replicated two times for each sample.

\subsection{Date Collection and Analysis}

Descriptive statistics including mean, minimum, maximum, variance and standard error were computed using the "Tabulate" option of JMP Genomics 7 (SAS Institute, Cary, NC). The distribution graph of the cowpea soluble contents was drawn using the "Distribution". Analysis of variance (ANOVA) was performed using the general linear model (GLM) of JMP Genomics 7. Student T-test at $\alpha=$ 0.05 was used for multiple comparisons of the least square mean (LSM) among the genotypes and the different seed colors.

\section{Results and Discussion}

\subsection{Soluble Sugar Quantification in Cowpea Seeds}

The soluble sugar content of cowpea seeds affects the final flavor of cowpea food and cowpea-derived products. This work was to use a simple, low-cost, spectrophotometric method for soluble sugar quantification in cowpea seeds. Significant variations were observed for soluble sugar contents in 113 diverse cowpea genotypes tested in this study (Table 1). The range in soluble sugar contents among tested samples was from $32.6 \mathrm{mg} / \mathrm{g}$ to $86.1 \mathrm{mg} / \mathrm{g}$ with an average of 54.5 $\mathrm{mg} / \mathrm{g}$, based on the standard cures, indicating seed soluble sugar contents having wide variations among the 113 cowpea genotypes. Soluble sugar content has a bimodal distribution (Table 1 and Figure 3).

The result of soluble sugar content in this experiment was apparently higher than previous report from other studies. Akpapunam et al. (1979) reported that the average of sucrose contents was $22 \mathrm{mg} / \mathrm{g}$ from 13 American cowpea (Vigna sinensis) varieties extracted by $70 \%$ ethanol [19]. Onigbinde and Akinyele (1983)

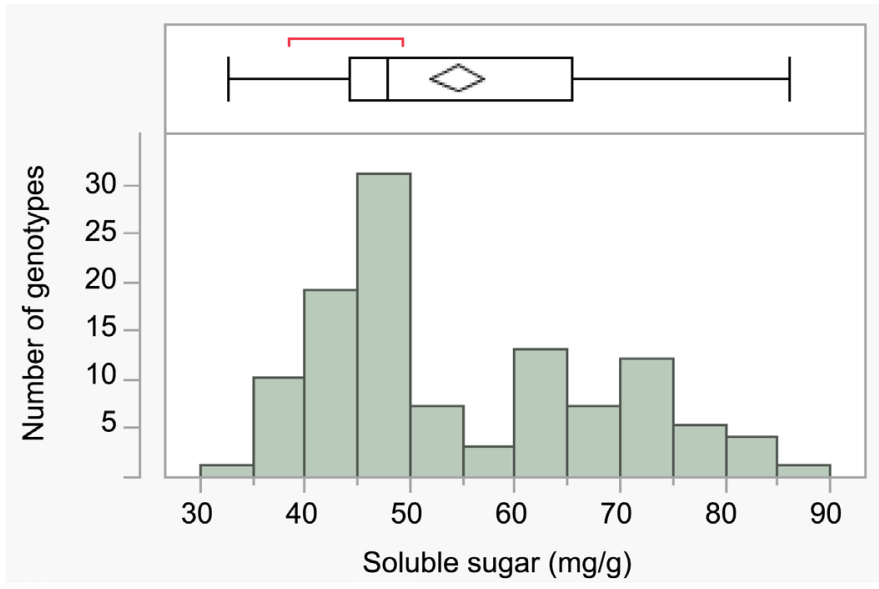

Figure 3. Distribution of soluble sugar content in cowpea seeds among 113 genotypes. 
reported that the average content of the sucrose was $8 \mathrm{mg} / \mathrm{g}$ in mature dry seeds of 20 varieties of cowpea grown in Nigeria [20]. Nassourou et al. (2017) reported the total soluble sugar content in cowpea seeds using the phenol sulfuric acid reagent method among 15 cowpea cultivars and observed that the highest values were $40.79 \mathrm{mg} / \mathrm{g}$ (IT93K-693-2) and $40.64 \mathrm{mg} / \mathrm{g}$ (BR1) with a mean of 22.31 $\mathrm{mg} / \mathrm{g}$ [17]. The content of soluble sugar in cowpea seeds in this study was obviously higher than what Onigbinde et al. (1983) and Nassourou et al. (2017) reported, which may be caused by different cowpea genotypes and extraction method. The result also was shown higher than that Akpapunam et al. (1979) reported due to their different species.

The top five genotypes with highest soluble sugar content in cowpea seeds were determined to be "Empire" (86.05 mg/g), PI583202 (84.53 mg/g), 09-655 $(82.05 \mathrm{mg} / \mathrm{g}), \mathrm{PI} 601085(81.57 \mathrm{mg} / \mathrm{g})$, and $09-529(80.94 \mathrm{mg} / \mathrm{g})$. In contrast, the USDA germplasm accession PI354832 (32.55 mg/g) and PI354865 (36.26 mg/g) had the lowest soluble sugar content among the 113 cowpea genotypes tested. Overall, the soluble sugar content in Arkansas cultivars and advanced breeding lines was higher than the USDA germplasm accessions. However, higher soluble sugar content was also observed in some USDA accessions such as PI583202 $(84.50 \mathrm{mg} / \mathrm{g})$ and PI601085 (81.60 mg/g). These results indicated that high level of soluble sugar content not only can be discovered from released cowpea cultivars, but also from cowpea germplasm. These cowpea genotypes with higher soluble sugar content will be beneficial to the future breeding program and genetic improvement for meeting the needs of the market and consumers.

\subsection{Compare Seed Soluble Sugar Content in Genetic Background}

A highly significant difference $(\mathrm{P}<0.001)$ was observed between Arkansas cowpea cultivars/advanced breeding lines and USDA cowpea germplasm accessions (Table 2). Most of the highest soluble sugar contents are found in Arkansas cowpea cultivars and advanced breeding lines. The average soluble sugar content of Arkansas cowpea cultivars/advanced breeding lines was $71.13 \mathrm{mg} / \mathrm{g}$, significantly higher than the average soluble sugar content of cowpea germplasm accessions $(50.04 \mathrm{mg} / \mathrm{g})$. Cowpea breeding program in University of Arkansas have had more than 60 years of history since the first variety "Monarch" was released in 1956. After selection and enhancement from generation to generation, the Arkansas cowpea cultivars/breeding lines have developed more closely to

Table 2. Descriptive statistic for soluble sugar $(\mathrm{mg} / \mathrm{g})$ by genetic background.

\begin{tabular}{ccccccccc}
\hline $\begin{array}{c}\text { Genetic } \\
\text { background }\end{array}$ & N & Mean & Std Dev & Min & Max & Variance & Std Err & $\begin{array}{c}\text { Prob }< \\
\mathbf{t}=\mathbf{0 . 0 5}\end{array}$ \\
\hline $\begin{array}{c}\text { AR cultivar/ } \\
\text { Breeding lines }\end{array}$ & 24 & 71.13 & 7.60 & 54.50 & 86.05 & 57.69 & 1.55 & $\mathrm{~A}$ \\
$\begin{array}{c}\text { USDA } \\
\text { Germplasm }\end{array}$ & 89 & 50.04 & 11.05 & 32.55 & 84.53 & 121.99 & 1.17 & $\mathrm{~B}$ \\
\hline
\end{tabular}


consumer's needs, including quality improvement and increasing breeder's expectation in seeds. Regardless of intentional or unintentional selection, the seed soluble sugar content of cowpea cultivars and advanced breeding lines has been also improved and increased after breeding and genetic improvement in Arkansas State and the Southern region of US (Table 2). These cultivars and advanced breeding lines exhibited more soluble sugar content and better adaptation to growing conditions in Arkansas State and the Southern region than USDA germplasm accessions.

\subsection{Soluble Sugar Content Evaluation in Different Seed Color}

Cowpea seed coat color is an important morphological character and commercial trait to costumers because of diversity of cowpea seed coat (Figure 4), which provides various products with colorful seed coat for consumers to choose in supermarket or grocery stores. In order to represent detailed cowpea seed coat color description in markets, ix major types of cowpea seed colors were used for this study: black, blackeye, browneye, cream, pinkeye, and red color. The variance of soluble sugar content in color coat seed was measured using GENESYS $^{\mathrm{TM}} 20$ Visible Spectrophotometer in this study (Table 1 and Table 3). The results showed that the pinkeye color cowpea seeds had the highest soluble sugar content averaging $72.42 \mathrm{mg} / \mathrm{g}$, and the black color cowpea contained the

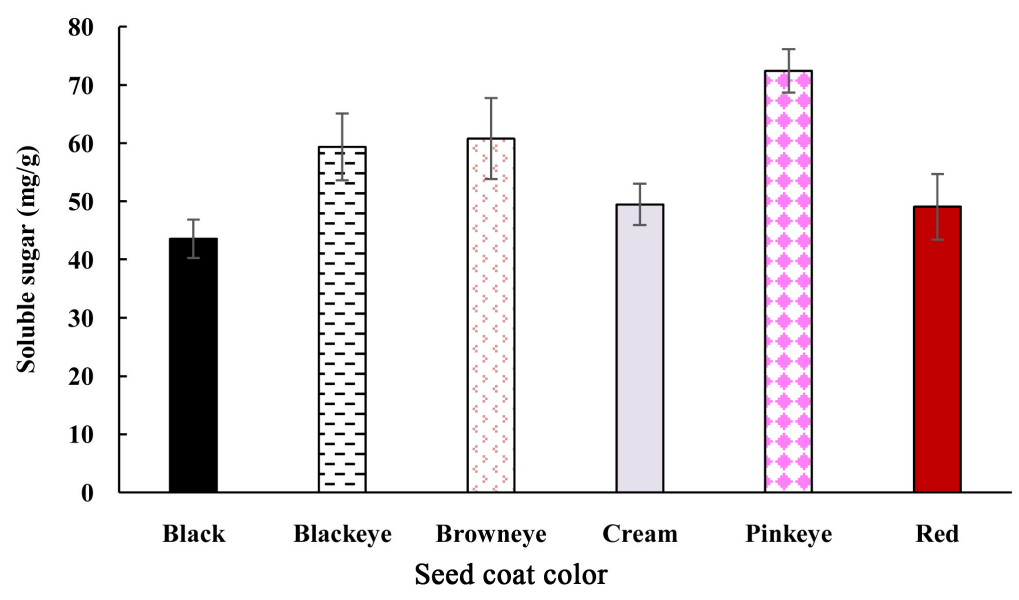

Figure 4. Average soluble sugar content $(\mathrm{mg} / \mathrm{g})$ per seed coat color.

Table 3. Descriptive statistics for soluble sugar ( $\mathrm{mg} / \mathrm{g})$ by seed coat color.

\begin{tabular}{ccccccccc}
\hline Seed Coat Color & N & Mean & Std Dev & Min & Max & Variance & Std Err & $\begin{array}{c}\text { Prob }< \\
\mathrm{t}=0.05\end{array}$ \\
\hline Pinkeye & 13 & 72.42 & 7.44 & 61.67 & 86.05 & 55.30 & 2.06 & $\mathrm{~A}$ \\
Browneye & 19 & 60.80 & 13.90 & 37.15 & 84.53 & 193.15 & 3.19 & $\mathrm{~B}$ \\
Blackeye & 23 & 59.38 & 11.39 & 42.86 & 80.94 & 129.76 & 2.38 & $\mathrm{~B}$ \\
Cream & 13 & 49.53 & 7.15 & 45.27 & 68.08 & 51.16 & 1.98 & $\mathrm{C}$ \\
Red & 17 & 49.08 & 11.30 & 40.42 & 77.20 & 127.71 & 2.74 & $\mathrm{C}$ \\
Black & 28 & 43.58 & 6.62 & 32.55 & 69.10 & 43.87 & 1.25 & $\mathrm{C}$ \\
\hline
\end{tabular}


lowest soluble sugar, averaging $43.58 \mathrm{mg} / \mathrm{g}$ in cowpea seeds. The browneye color $(60.80 \mathrm{mg} / \mathrm{g})$ contained almost similar amount of soluble sugar compared with that of blackeye color $(59.38 \mathrm{mg} / \mathrm{g})$. Overall, the soluble sugar content in pinkeye color $(72.42 \mathrm{mg} / \mathrm{g})>$ browneye $(60.80 \mathrm{mg} / \mathrm{g}) \geq$ blackeye $(59.39 \mathrm{mg} / \mathrm{g})>$ cream $(49.53 \mathrm{mg} / \mathrm{g}) \geq$ red $(49.08 \mathrm{mg} / \mathrm{g}) \geq$ black $(43.58 \mathrm{mg} / \mathrm{g})$. This study will inform consumers to buy which type of the seed color cowpea that fits their needs in terms of cooking quality and sweetness.

\section{Conclusion}

A total of 113 cowpea genotypes were measured for their soluble sugar contents in seeds using Spectrophotometer by phenol-sulphuric acid method in this study. A wide range of solublesugar content were observed from $86.05 \mathrm{mg} / \mathrm{g}$ to $32.55 \mathrm{mg} / \mathrm{g}$ with an average of $54.52 \mathrm{mg} / \mathrm{g}$. Commercial cultivars and advanced breeding lines from Arkansas region, USA contained higher soluble sugar content than USDA germplasm did. The soluble sugar content changed with the seed color coat: pinkeye $(72.42 \mathrm{mg} / \mathrm{g})>$ browneye $(60.80 \mathrm{mg} / \mathrm{g}) \geq$ blackeye $(59.38 \mathrm{mg} / \mathrm{g})>$ cream $(49.53 \mathrm{mg} / \mathrm{g}) \geq \operatorname{red}(49.08 \mathrm{mg} / \mathrm{g}) \geq$ black $(43.58 \mathrm{mg} / \mathrm{g})$.

\section{References}

[1] Baptiste, N.T.J., Youmbi, E., Njintang, N.Y. and Youmbi, E. (2011) Generation Means Analysis of Seed Sucrose Content in Cowpea (Vigna unguiculata L. Walp.). Asian Journal of Agricultural Sciences, 3, 4795-4805.

[2] Namasaka, R.W., Tusiime, G., Orawu, M., Gibson, P., Nyiramugisha, J. and Edema, R. (2017) Evaluation of Cowpea Genotypes for Resistance to Fusarium redolens in Uganda. American Journal of Political Science, 8, 2296-2314.

[3] Nassourou, M.A., Noubissié, T.J.B., Njintang, Y.N. and Bell, J.M. (2017) Diallel Analyses of Soluble Sugar Content in Cowpea (Vigna unguiculata L. Walp.). The Crop Journal, 5, 556-559. https://doi.org/10.1016/j.cj.2017.05.005

[4] Ravelombola, W.S, Shi, A., Weng, Y., Motes, D., Chen, P., Srivastava, V. and Wingfield, C. (2016) Evaluation of Total Seed Protein Content in Eleven Arkansas Cowpea (Vigna unguiculata (L.) Walp.) Lines. American Journal of Political Science, 7, 2288-2296.

[5] Roberts, P.A., Cisse, N., Drabo, I., Dovala, A.C. and Ehlers, J. (2008) Modern Cowpea Breeding to Overcome Critical Production Constraints in Africa and the US. http://www.canr.msu.edu/legumelab/uploads/files/UCR-1\%20Tech\%20Prog\%20Rp t\%20FY08\%20Final.pdf

[6] Weng, Y., Shi, A., Ravelombola, W.S., Yang, W., Qin, J., Motes, D., Moseley, D.O. and Chen, P. (2017) A Rapid Method for Measuring Seed Protein Content in Cowpea (Vigna unguiculata (L.) Walp.). American Journal of Political Science, 8, 2387-2396.

[7] Xiong, H., Shi, A., Mou, B., Qin, J., Motes, D., Lu, W., Ma, J., Weng, Y., Yang, W. and $\mathrm{Wu}$, D. (2016) Genetic Diversity and Population Structure of Cowpea (Vigna unguiculataL. Walp). PLoS ONE, 11, e0160941. https://doi.org/10.1371/journal.pone.0160941

[8] Singh, B. (2003) Improving the Production and Utilization of Cowpea as Food and Fodder. Field Crops Research, 84, 169-150.

https://doi.org/10.1016/S0378-4290(03)00148-5 
[9] Olufajo, O.O. (2012) Agronomic Performance of Improved Cowpea Varieties under Natural Infestation with Alectra vogelii (Benth.) in the Northern Guinea Savannah of Nigeria. Agricultura Tropica et Subtropica, 45, 66-71. https://doi.org/10.2478/v10295-012-0011-x

[10] Ngalamu, T., Odra, J. and Tongun, N. (2014) Cowpea Production Handbook https://www.researchgate.net/publication/284900187_Cowpea_Production_Handbo ok

[11] Basha, S.M. (1992) Soluble Sugar Composition of Peanut Seed. Journal of Agricultural and Food Chemistry, 40, 780-783. https://doi.org/10.1021/jf00017a015

[12] Hou, A., Chen, P., Shi, A., Zhang, B. and Wang, Y.-J. (2009) Sugar Variation in Soybean Seed Assessed with a Rapid Extraction and Quantification Method. International Journal of Agronomy, 2009, Article ID: 484571.

https://doi.org/10.1155/2009/484571

[13] Teixeira, A.I., Ribeiro, L.F., Rezende, S.T., Barros, E.G. and Moreira, M.A. (2012) Development of a Method to Quantify Sucrose in Soybean Grains. Food Chemistry, 130, 1134-1136. https://doi.org/10.1016/j.foodchem.2011.07.128

[14] Rosa, M., Prado, C., Podazza, G., Interdonato, R., González, J.A., Hilal, M. and Prado, F.E. (2009) Soluble Sugars-Metabolism, Sensing and Abiotic Stress: A Complex Network in the Life of Plants. Plant Signaling \& Behavior, 4, 388-393. https://doi.org/10.4161/psb.4.5.8294

[15] Pukacka, S. and Pukacki, P.M. (1997) Changes in Soluble Sugars in Relation to Desiccation Tolerance and Effects of Dehydration on Freezing Characteristics of Acer platanoides and Acer pseudoplatanus Seeds. Acta Physiologiae Plantarum, 19, 147-154. https://doi.org/10.1007/s11738-997-0031-8

[16] Steadman, K.J., Pritchard, H.W. and Dey, P.M. (1996) Tissue-Specific Soluble Sugars in Seeds as Indicators of Storage Category. Annals of Botany, 77, 667-674. https://doi.org/10.1093/aob/77.6.667

[17] Blackman, S.A., Obendorf, R.L. and Leopold, A.C. (1992) Maturation Proteins and Sugars in Desiccation Tolerance of Developing Soybean Seeds. Plant Physiology, 100, 225-230. https://doi.org/10.1104/pp.100.1.225

[18] Michel, D., Gilles, K.A., Hamilton, J.K., Rebers, P.A. and Fred, S. (1956) Colorimetric Method for Determination of Sugars and Related Substances. Analytical Chemistry, 28, 350-356. https://doi.org/10.1021/ac60111a017

[19] Akpapunam and Markakis (1979) Oligosaccharides of 13 American Cultivars of Cowpea (Vignasinensis). Journal of Food Science, 44, 1317-1319. https://doi.org/10.1111/j.1365-2621.1979.tb06428.x

[20] Onigbinde and Akinyele (1983) Oligosaccharide Content of 20 Varieties of Cowpeas in Nigeria. Journal of Food Science, 48, 1250-1251. https://doi.org/10.1111/j.1365-2621.1983.tb09203.x 